\title{
STUDI IDENTIFIKASI RISIKO PADA PROYEK INFRASTRUKTUR DI INDONESIA
}

\author{
Wilwin $^{1}$ dan Arianti Sutandi ${ }^{2}$ \\ ${ }^{1}$ Program Studi Sarjana Teknik Sipil, Universitas Tarumanagara, Jl. Letjen S. Parman No.1 Jakarta \\ wilwin.325170043@stu.untar.ac.id \\ ${ }^{2}$ Program Studi Sarjana Teknik Sipil, Universitas Tarumanagara, Jl. Letjen S. Parman No.1 Jakarta \\ ariantis@ft.untar.ac.id
}

Masuk: 14-01-2021, revisi: 02-03-2021, diterima untuk diterbitkan: 17-03-2021

\begin{abstract}
Infrastructure projects such as buildings and transportation infrastructure have many risks and uncertainties in the implementation process. To minimize this risk, it is necessary to apply risk management in project implementation. In this study, a literature study was conducted to analyze the risk identification methods and potential risks involved in Indonesia's infrastructure projects. An analysis was conducted by comparing the risk identification method and the risk potential in the infrastructure project risk journal collected using the basic mathematic method. Based on research, the most widely discussed identification method is the questionnaire. Furthermore, a risk comparison was carried out in the 2 most discussed categories. The checklist method was carried out so that the material and equipment, and humans were obtained as the most discussed category. The results showed that in building projects, the most discussed risk was the increase in material prices (71\%) in the material and equipment category and labor accidents (86\%) in the human category. Meanwhile, in transportation infrastructure projects, the most discussed risks were unavailability or shortage of material (67\%) in the material and equipment category and the low quality of labor (83\%) in the human category.
\end{abstract}

Keywords: risk identification; construction risk; infrastructure project

\section{ABSTRAK}

Proyek infrastruktur seperti bangunan gedung dan prasarana transportasi memiliki banyak risiko dan ketidakpastian dalam proses pelaksanaannya. Untuk meminimalkan risiko tersebut perlu diterapkannya manajemen risiko didalam pelaksanaan proyeknya. Dalam penelitian ini dilakukan studi literatur untuk menganalisa metode identifikasi risiko dan potensi risiko yang terdapat pada proyek infrastruktur di Indonesia. Dilakukan analisa dengan melakukan perbandingan metode identifikasi risiko dan potensi risiko pada jurnal risiko proyek infrastruktur yang telah dikumpulkan menggunakan metode matematis sederhana. Berdasarkan penelitian, metode identifikasi yang paling banyak dibahas adalah kuisioner. Selanjutnya dilakukan perbandingan risiko pada 2 kategori yang paling banyak dibahas, penentuan kategori ini dilakukan dengan metode checklist sehingga didapatkan kategori material dan peralatan, dan manusia sebagai kategori yang paling banyak dibahas. Hasil penelitian menunjukkan bahwa pada proyek bangunan gedung, risiko yang paling banyak dibahas adalah kenaikan harga material (71\%) pada kategori material dan peralatan dan kecelakaan tenaga kerja (86\%) pada kategori manusia. Sedangkan pada proyek prasarana transportasi, risiko yang paling banyak dibahas adalah tidak tersedianya atau kekurangan material $(67 \%)$ pada kategori material dan peralatan dan rendahnya kualitas tenaga kerja (83\%) pada kategori manusia.

Kata kunci: identifikasi risiko; risiko konstruksi; proyek infrastruktur

\section{PENDAHULUAN}

Pada pelaksanaan konstruksi sering sekali terjadi kendala atau risiko yang tidak terduga. Risiko atau kendala yang terjadi juga bervariasi bergantung pada keadaan, letak, tipe bangunan akan dibangun. Risiko ini sendiri dapat mempengaruhi produktivitas, kualitas, kinerja dan biaya yang dikeluarkan dari suatu proyek. Risiko yang terjadi pada pelaksanaan konstruksi sering sekali tidak terduga, walaupun suatu proyek telah dipersiapkan sematang mungkin. Maka dari itu diperlukanlah solusi untuk meminimalisir risiko yang terjadi tersebut.

Risiko pada proyek konstruksi tidak dapat dihilangkan tetapi dapat dikurangi atau dipindahkan dari satu pihak ke pihak lainnya (Kangari, 1995), jadi dapat dikatakan bahwa risiko yang terjadi tidak dapat dihilangkan sebagaimanapun caranya, tetapi dapat diminimalisir dan disalurkan. Dikarenakan penelitian mengenai risiko ini 
penting maka dibuatlah suatu sistem managemen yang menganalisis risiko-risiko yang terjadi atau sebutan umumnya adalah manajemen risiko. Manajemen risiko ini berfungsi untuk mengidentifikasi, menganalisa, menelaah, dan mempertimbangkan dampak risiko yang mungkin terjadi pada proyek serta memberi solusi untuk masalah atau risiko yang mungkin terjadi.

Tahapan pertama sekaligus tahapan yang sangat penting pada manajemen risiko adalah identifikasi risiko karena tahapan selanjutnya baru bisa dilakukan apabila tahap identifikasi telah dilakukan. Dalam proses identifikasi risiko, risiko yang diutamakan adalah risiko yang memberikan dampak dan pengaruh yang besar terhadap suatu proyek, risiko yang diidentifikasi bisa didapat dari pengalaman proyek atau melalui studi yang memfokuskan mengenai kegiatan atau komponen yang berpotensi mempengaruhi suatu proyek. Untuk mengidentifikasikan suatu risiko, metode yang tepat serta efektif diperlukan dalam memproses suatu risiko. Ada beberapa teknik yang dapat dilakukan untuk mengidentifikasikan risiko menurut (Nasir B. Siraj \& Aminah Robinson Fayek, 2019), antara lain: brainstorming (pertukaran pikiran), questionnaire survey (kuisioner), literature review (studi literatur), documentation review (studi dokumentasi), expert interview (wawancara ahli), delphi technique (teknik delphi), checklist (membuat daftar pemeriksaan) dan sebagainya. Sumber risiko yang berpotensi dikumpulkan dari beberapa jurnal yang membahas risiko konstruksi di Indonesia, lalu dilakukanlah perbandingan antara jurnal yang sudah dikumpulkan mengenai risiko serta metode yang digunakan dalam mengidentifikasinya.

Tujuan yang ingin dicapai dari penelitian ini adalah untuk mengetahui risiko dan metode identifikasi risiko yang paling banyak dibahas pada proyek konstruksi infrastruktur di Indonesia dan mengetahui perbedaan risiko pada jenis proyek infrastruktur yang berbeda.

\section{Risiko}

Risiko merupakan variasi dalam hal-hal yang mungkin terjadi secara alami didalam suatu situasi (Fisk, 1997). Secara umum risiko dikaitkan dengan kemungkinan (probabilitas) terjadinya peristiwa diluar yang diharapkan (Soeharto, 1995). Risiko adalah ancaman terhadap kehidupan, property atau keuntungan finansial akibat bahaya yang terjadi (Duffield, 1999). Definisi risiko menurut (Hanafi, 2006) risiko merupakan besarnya penyimpangan antara tingkat pengembalian yang diharapkan (expected return-ER) dengan tingkat pengembalian actual (actual return). Risiko adalah suatu kejadian atau kondisi yang tidak pasti, yang apabila terjadi dapat berdampak pada tujuan proyek yang mencakup ruang lingkup, jadwal, biaya dan kualitas (PMBOK, 2008). Dari beberapa pengertian menurut para ahli diatas dapat disimpulkan bahwa suatu variasi dari hal-hal yang mungkin terjadi secara tidak terduga yang dapat mengakibatkan kerugian maupun ancaman terhadap keberlangsungannya suatu kejadian.

\section{Manajemen risiko}

Manajemen risiko proyek meliputi proses penerapan rencana manajemen risiko, identifikasi, analisis dan pengendalian proyek. Tujuan manajemen risiko dalam proyek konstruksi adalah untuk meningkatkan kemungkinan dan dampak kegiatan aktif, dan untuk mengurangi kemungkinan dan dampak faktor-faktor yang tidak menguntungkan dalam proyek tersebut (PMBOK, 2008). Secara langsung manajemen risiko yang efektif dapat menghindari sebanyak mungkin dari biaya-biaya yang terpaksa harus dikeluarkan akibat terjadinya suatu kejadian yang merugikan dan menghambat peningkatan keuntungan usaha (Soemarno, 2007).

\section{Identifikasi risiko}

Menurut (Darmawi, 2008) Tahap pertama dari proses manajemen risiko adalah tahap identifikasi risiko. Identifikasi risiko merupakan proses yang dilakukan secara sistematis dan berkesinambungan untuk mengidentifikasi kemungkinan risiko atau kerugian atas kekayaan, hutang, dan personil perusahaan. Proses identifikasi ini merupakan proses pertama sekaligus terpenting, karena dari proses inilah semua risiko yang ada atau mungkin terjadi pada proyek dapat diidentifikasi.

Masih menurut (Darmawi, 2008) proses identifikasi harus dilakukan secara cermat dan komperhensif, sehingga tidak ada risiko yang terlewatkan atau tidak teridentifikasi. Dalam pelaksanaannya, identifikasi risiko dapat dilakukan dengan beberapa teknik, antara lain :
a. Brainstorming
b. Questionnaire
c. Industry Benchmarking
d. Scenario Analysis
e. Risk Assessment Workshop
f. Incident Investigation 


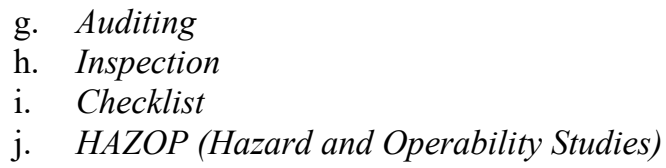

\section{Jenis risiko konstruksi}

Dalam mengidentifikasi risiko, beberapa ahli membaginya menjadi beberapa kategori, diantaranya:

Tabel 1. Kategori risiko

\begin{tabular}{|c|c|c|}
\hline No & Kategori risiko & Sumber referensi \\
\hline 1 & Risiko eksternal & \multirow{4}{*}{ (Kerzner, 1995) } \\
\hline 2 & Risiko internal & \\
\hline 3 & Risiko teknis & \\
\hline 4 & Risiko legal & \\
\hline 1 & Risiko yang berhubungan dengan konstruksi & \multirow{5}{*}{ (Fisk, 1997) } \\
\hline 2 & Risiko fisik & \\
\hline 3 & Risiko kontraktual dan legal risiko pelaksanaan & \\
\hline 4 & Risiko ekonomi & \\
\hline 5 & Risiko politik dan umum & \\
\hline 1 & Risiko finansial & \multirow{5}{*}{ (Shen, Wu, Ng, 2001) } \\
\hline 2 & Risiko legal & \\
\hline 3 & Risiko manajemen & \\
\hline 4 & Risiko pasar & \\
\hline 5 & Risiko politik dan kebijakan risiko teknis & \\
\hline 1 & Risiko teknologi & \multirow{7}{*}{$\begin{array}{l}\text { (Loosemore, Raftory, } \\
\text { Reilly, Higgon, 2006) }\end{array}$} \\
\hline 2 & Risiko manusia & \\
\hline 3 & Risiko lingkungan & \\
\hline 4 & Risiko komersial dan legal & \\
\hline 5 & Risiko manajemen & \\
\hline 6 & Risiko ekonomi dan finansial risiko partner bisnis & \\
\hline 7 & Risiko politik & \\
\hline 1 & Risiko finansial dan ekonomi & \multirow{6}{*}{$\begin{array}{l}\text { (Al-Bahar dan } \\
\text { Crandall, 1990) }\end{array}$} \\
\hline 2 & Risiko desain & \\
\hline 3 & Risiko politik dan lingkungan & \\
\hline 4 & Risiko yang berhubungan dengan konstruksi & \\
\hline 5 & Risiko fisik & \\
\hline 6 & Risiko bencana alam & \\
\hline
\end{tabular}

\section{Infrastruktur}

Secara umum, infrastruktur dapat diartikan sebagai bangunan dan fasilitas fisik dan sosial dasar, seperti: gedung, jalan tol, pasokan listrik, dan berbagai barang yang dibutuhkan untuk kegiatan masyarakat atau layanan publik. Infrastruktur adalah segala fasilitas yang dibutuhkan oleh masyarakat biasa untuk menunjang berbagai aktivitas masyarakat dalam kehidupan sehari-hari. Dengan kata lain, Infrastruktur adalah segala fasilitas berwujud dan tidak berwujud yang dibangun oleh pemerintah dan perseorangan untuk memenuhi kebutuhan dasar masyarakat dalam menunjang kehidupan sosial dan masyarakat itu sendiri. 


\section{METODE PENELITIAN}

\section{Prosedur penelitian}

Prosedur penelitian yang dilakukan pada penelitian ini dapat diuraikan sebagai berikut:

1. Tahap pertama dari penelitian ini adalah melakukan studi mengenai identifikasi risiko, manajemen risiko, metode identifikasi risiko dan penanganan risiko pada proyek konstruksi.

2. Tahap kedua dari penelitian ini adalah mengumpulkan data berupa risiko konstruksi yang mungkin terjadi pada proyek infrastruktur, metode identifikasi yang digunakan pada proyek infrastruktur. Data yang didapatkan berasal dari jurnal-jurnal yang bersangkutan dengan risiko-risiko konstruksi yang mungkin terjadi pada proyek konstruksi infrastruktur di Indonesia.

3. Selanjutnya dilakukan perbandingan mengenai data risiko konstruksi di Indonesia dan metode identifikasi yang digunakan pada proyek infrastruktur di wilayah berbeda di Indonesia.

4. Tahap terakhir adalah membuat kesimpulan dan saran dari studi yang dilakukan.

\section{Perbandingan data}

Data risiko konstruksi yang dibandingkan dibatasi berdasarkan kategori yang sudah ditentukan, beberapa kategori yang menjadi batasan perbandingan data tersebut adalah:

1. Material and Tool (bahan dan peralatan)

2. Man (manusia)

Perbandingan akan dilakukan menggunakan metode yang mengacu pada jurnal ASCE oleh (Nasir B. Siraj \& Aminah Robinson Fayek, 2019) yang berjudul "Risk Identification and Common Risks in Construction: Literature Review and Content Analysis". Perbandingan akan dibuat dalam tabel untuk mempermudah penelitian data.

\section{HASIL DAN PEMBAHASAN}

\section{Data untuk penelitian}

Data yang akan digunakan adalah karya tulis dalam bentuk jurnal yang berhubungan dengan risiko konstruksi infrastruktur. Jurnal yang telah didapat berjumlah 13 jurnal, dengan 7 jurnal dikategorikan sebagai bangunan infrastruktur gedung, dan 6 jurnal dikategorikan sebagai bangunan infrastruktur prasarana transportasi.

\section{Perbandingan data}

Data dari 13 jurnal yang telah dikumpulkan diteliti lalu diklasifikasikan. Setelah diklasifikasi, lalu dibuat perbandingan metode identifikasi risiko konstruksi dan jumlah metode identifikasi yang digunakan pada proyek yang diteliti. Hasil dari perbandingan tersebut adalah: metode identifikasi yang dang paling banyak digunakan adalah Kuisioner yang digunakan oleh 12 artikel dengan persentase $92 \%$ dari keseluruhan artikel yang digunakan dan jumlah metode identifikasi yang paling sering digunakan adalah 2 jenis metode identifikasi yang digunakan oleh 6 artikel dengan persentase $46 \%$ dari keseluruhan artikel yang digunakan.

Berikut adalah tabel perbandingan metode identifikasi dan jumlah metode identifikasi yang telah diteliti:

Tabel 2. Perbandingan metode identifikasi risiko

\begin{tabular}{cccc}
\hline Metode identifikasi & Jumlah artikel & Persentase artikel (\%) & Peringkat \\
\hline Wawancara & 9 & $69 \%$ & 2 \\
Kuisioner & 12 & $92 \%$ & 1 \\
Studi Literatur & 3 & $23 \%$ & 3 \\
Brainstorming & 1 & $8 \%$ & 5 \\
Investigasi Lapangan & 2 & $15 \%$ & 4 \\
\hline
\end{tabular}


Tabel 3. Perbandingan metode identifikasi risiko

\begin{tabular}{cccc}
\hline $\begin{array}{c}\text { Jenis Metode } \\
\text { identifikasi }\end{array}$ & Jumlah artikel & Persentase artikel (\%) & Peringkat \\
\hline $\begin{array}{c}1 \text { jenis metode } \\
\text { identifikasi } \\
2 \text { jenis metode } \\
\text { identifikasi }\end{array}$ & 3 & $23 \%$ & 1 \\
$\begin{array}{c}3 \text { jenis metode } \\
\text { identifikasi atau lebih }\end{array}$ & 6 & $46 \%$ & 2 \\
\hline Total Artikel $=$ & 13 & $31 \%$ & \\
\hline
\end{tabular}

\section{Pengolahan data}

Data yang telah diklasifikasi akan ditentukan kategori risiko yang paling banyak dibahas. Penentuan kategori risiko yang paling banyak dibahas dilakukan dengan cara checklist, untuk setiap jurnal yang memiliki kategori yang disebutkan akan mendapatkan angka 1, lalu angka tersebut dikumulatifkan untuk setiap kategori risiko, didapatkan 2 kategori risiko yang paling banyak dibahas dengan nilai total paling besar dari 13 jurnal yang digunakan yaitu Material dan Peralatan yang dibahas pada 10 dari 13 artikel dan Manusia yang dibahas pada 11 dari 13 artikel. Berikut adalah tabel penentuan kategori risiko dominan yang telah dibuat dalam excel:

Tabel 4. Checklist kategori risiko yang paling banyak dibahas

\begin{tabular}{|c|c|c|c|c|c|c|c|c|c|c|c|c|c|c|}
\hline \multirow{2}{*}{ Jenis Kategori Risiko } & \multicolumn{13}{|c|}{ Jurnal ke- } & \multirow{2}{*}{ Tota } \\
\hline & 1 & 2 & 3 & 4 & 5 & 6 & 7 & 8 & 9 & 10 & 11 & 12 & 13 & \\
\hline Force Majeur & 1 & & & 1 & & & & & & 1 & & & & 3 \\
\hline Material dan Peralatan & 1 & 1 & 1 & 1 & 1 & 1 & 1 & 1 & & & 1 & & 1 & 10 \\
\hline Manusia & 1 & & 1 & 1 & 1 & 1 & 1 & 1 & 1 & 1 & & 1 & 1 & 11 \\
\hline Lingkungan & 1 & & & & 1 & & 1 & 1 & 1 & 1 & & & & 6 \\
\hline Design dan Teknologi & 1 & & & & & & & & & 1 & & & & 2 \\
\hline Manajemen & 1 & 1 & & 1 & & & 1 & & & 1 & & & & 5 \\
\hline Finansial & & 1 & & & & & 1 & & & & & & & 2 \\
\hline Konstruksi & & 1 & & 1 & 1 & & 1 & & & 1 & 1 & 1 & 1 & 8 \\
\hline Kesehatan dan Keselamatan Kerja & & 1 & 1 & & 1 & & & & 1 & & & 1 & 1 & 6 \\
\hline Sosial & & 1 & & & & & & & & & 1 & & & 2 \\
\hline Politik & & 1 & & & 1 & & & & 1 & 1 & 1 & 1 & 1 & 7 \\
\hline Teknis & & & 1 & & 1 & & 1 & 1 & 1 & & & 1 & 1 & 7 \\
\hline Kontrak & & 1 & & 1 & & & & & & & 1 & & & 3 \\
\hline Ekonomi dan Keuangan & & & & & 1 & & 1 & & 1 & & & 1 & 1 & 5 \\
\hline Pelaksanaan & & & & 1 & & & & & & & 1 & & & 2 \\
\hline Perencanaan & & & & & 1 & & & & & 1 & & & & 2 \\
\hline Pemasaran & & & & & 1 & & & & 1 & & & & & 2 \\
\hline Logistik & & & & & & 1 & & & & & & & & 1 \\
\hline Alam & & 1 & & & & 1 & 1 & & 1 & & 1 & 1 & & 6 \\
\hline Proyek & & & & & 1 & & 1 & & 1 & & & 1 & 1 & 5 \\
\hline Biaya & & & & & & & & 1 & & & 1 & & & 2 \\
\hline Waktu & & & & & & & & 1 & & & 1 & & & 2 \\
\hline Faktor Eksternal & & & & & & & & 1 & & & & & & 1 \\
\hline Mutu & & & & & & & & & & & 1 & & & 1 \\
\hline
\end{tabular}


Dari kedua kategori risiko yang paling banyak dibahas tersebut akan dilakukan perbandingan risiko antara proyek infrastruktur berjenis bangunan gedung dan prasarana transportasi. Berikut adalah tabel hasil perbandingan risiko dari proyek infrastruktur berjenis bangunan gedung dan prasarana transportasi yang telah diteliti:

Tabel 5. Perbandingan risiko konstruksi bangunan gedung

\begin{tabular}{|c|c|c|c|c|}
\hline Kategori risiko & Risiko Konstruksi & $\begin{array}{c}\text { Jumlah } \\
\text { artikel }\end{array}$ & $\begin{array}{l}\text { Persentase } \\
\text { artikel }(\%)\end{array}$ & Peringkat \\
\hline \multirow{8}{*}{ Material dan Peralatan } & Kerusakan atau kehilangan material & 3 & $43 \%$ & 4 \\
\hline & Keterlambatan pengiriman material & 3 & $43 \%$ & 4 \\
\hline & Tidak tersedianya atau kekurangan material & 4 & $57 \%$ & 2 \\
\hline & Kenaikan harga material & 5 & $71 \%$ & 1 \\
\hline & Kualitas atau mutu material tidak sesuai & 4 & $57 \%$ & 2 \\
\hline & Peralatan tidak layak atau rusak & 3 & $43 \%$ & 4 \\
\hline & Keterlambatan pengiriman peralatan & 2 & $29 \%$ & 7 \\
\hline & Total $=$ & 7 & & \\
\hline \multirow{8}{*}{ Manusia } & Kurangnya koordinasi antar pekerja & 2 & $29 \%$ & 5 \\
\hline & Produktivitas tenaga kerja rendah & 2 & $29 \%$ & 5 \\
\hline & Rendahnya kualitas tenaga kerja & 5 & $71 \%$ & 2 \\
\hline & Perselisihan tenaga kerja & 3 & $43 \%$ & 4 \\
\hline & Pemogokan tenaga kerja & 4 & $57 \%$ & 3 \\
\hline & Kurang tersedianya tenaga kerja & 1 & $14 \%$ & 7 \\
\hline & Kecelakaan tenaga kerja & 6 & $86 \%$ & 1 \\
\hline & Total $=$ & 7 & & \\
\hline
\end{tabular}

Tabel 6. Perbandingan risiko konstruksi prasarana transportasi

\begin{tabular}{ccccc}
\hline Kategori risiko & Risiko Konstruksi & $\begin{array}{c}\text { Jumlah } \\
\text { artikel }\end{array}$ & $\begin{array}{c}\text { Persentase } \\
\text { artikel (\%) }\end{array}$ & Peringkat \\
\hline & Tidak tersedianya atau kekurangan material & 4 & $67 \%$ & 1 \\
& Kualitas atau mutu material tidak sesuai & 2 & $33 \%$ & 3 \\
Material dan Peralatan & Keterlambatan pengiriman material & 3 & $50 \%$ & 2 \\
& Kenaikan harga material & 1 & $17 \%$ & 6 \\
& Kerusakan atau kehilangan material & 2 & $33 \%$ & 3 \\
& Peralatan yang tidak layak atau rusak & 2 & $33 \%$ & 3 \\
& Keterlambatan pengiriman peralatan & 1 & $17 \%$ & 6 \\
\hline & Total = & 6 & & 5 \\
\hline Kanusia & Kurangnya koordinasi antar pekerja & 1 & $17 \%$ & 2 \\
& Kurang tersedianya tenaga kerja & 3 & $50 \%$ & 2 \\
& Produktivitas tenaga kerja rendah & 3 & $50 \%$ & 1 \\
Rendahnya kualitas tenaga kerja & 5 & $83 \%$ & 4 \\
\hline
\end{tabular}

\section{Pembahasan}

Berikut adalah pembahasan mengenai risiko yang paling banyak dibahas pada proyek bangunan gedung berdasarkan Tabel 5: 


\section{Kenaikan harga material ( $71 \%)$ :}

- Menurut (Siahaan, 2015), pada konstruksi bangunan gedung terutama pada bangunan gedung komersial memiliki harga material-material yang cukup mahal. Hal ini disebabkan karena pada pekerjaan gedung memiliki komponenkomponen struktur maupun aksesoris struktur yang bervariasi, contohnya adalah lift, escalator, shaft, bahkan komponen seperti keramik dan marmer memiliki harga yang terbilang cukup tinggi.

- Menurut (Mustami, 2017) kenaikan harga bahan bangunan tampak pada Indeks Harga Perdagangan Besar (IHPB) yang dicatat oleh Badan Pusat Statistik (BPS). Kenaikan harga bahan bangunan rata-rata setiap bulannya mencapai $0,28 \%$ dibanding bulan sebelumnya. Kenaikan harga ini terus melonjak terutama pada harga komoditas besi beton, kawat, paku, mur, baut, besi lainnya dan bahan bangunan dari aluminium. Hal ini dapat menjadi alasan mengapa risiko yang paling sering dibahas pada kategori material dan peralatan pada proyek bangunan gedung dipegang oleh kenaikan harga material.

\section{Kecelakaan tenaga kerja (86\%):}

- Menurut (Iwan M. Ramdan, 2016) kecelakaan pada proyek konstruksi dapat terjadi akibat 2 faktor, yaitu akibat personil kerja dan lingkungan. Kecelakaan akibat personil kerja biasanya memiliki hubungan yang signifikan antara stress kerja dan kelelahan kerja, tindakan tidak aman, dan prosedur pelatihan kejadian kecelakaan di tempat kerja yang kurang memadai. Dan Kecelakaan akibat lingkungan biasanya disebabkan oleh mesin dan peralatan kerja yang tidak memadai dan lingkungan kerja yang tidak aman. Kecelakaan yang paling sering terjadi adalah tertimpa benda, terjatuh dari ketinggian, terpeleset, tertusuk/tersayat benda tajam.

- Menurut (Novita Sari, 2013) salah satu pekerjaan yang rentan menyebabkan kecelakaan pada proyek bangunan gedung cenderung berhubungan dengan ketinggian (vertikal), kecelakaan yang sering terjadi seperti pekerja terjatuh saat sedang berada di elevasi yang tinggi dan kecelakaan akibat tertimpa komponen struktur maupun alat berat yang berada di atas pekerja. Data dari International Labour Organization (ILO) tahun 2015 menyebutkan, dari 142 kematian akibat kecelakaan kerja, penyebab utamanya adalah jatuh dari ketinggian sebesar $45 \%$. Contoh pekerjaan yang berhubungan pada ketinggian seperti pemasangan scaffolding, pemasangan kerangka gedung, pemasangan atap, pemasangan plafon, pengangkutan material dengan tower crane dan lainnya.

Berikut adalah pembahasan mengenai risiko yang paling banyak dibahas pada proyek prasarana transportasi berdasarkan Tabel 6:

1. Tidak tersedianya atau kekurangan material (67\%):

- Risiko tidak tersedianya atau kekurangan material sering terjadi pada proyek pembangunan infrastruktur. Menurut (Fahmi Wati Iribaram, 2018) salah satu penyebab dari kekurangan material adalah kurang kompetennya pihak quantity surveyor dalam menentukan jumlah kebutuhan material yang diperlukan dalam pembangunan proyek tersebut, sehingga jumlah material yang datang tidak sesuai dengan yang diperlukan. Penyebab lainnya ialah kurangnya supplier material dalam menyediakan material yang dibutuhkan pada proyek. Pada proyek pembangunan prasarana transportasi seperti jalan raya maupun jalan tol biasanya memerlukan material yang cukup banyak dikarenakan volume pekerjaan konstruksi yang besar, hal ini menyebabkan pada proyek pembangunan prasarana transportasi sering mengalami kekurangan bahan dan material.

\section{Rendahnya kualitas tenaga kerja (83\%):}

- Menurut (Prasetyo, 2012) rendahnya kualitas tenaga/personil kerja pada suatu proyek konstruksi sangat berpengaruh pada kualitas pekerjaan konstruksi, rendahnya kualitas tenaga kerja ini biasa disebabkan karena kurangnya keterampilan dan pengalaman dari personil atau pekerja dalam melakukan pekerjaannya. Rendahnya kualitas personil kerja menyebabkan menurunnya produktivitas yang dimana dapat menyebabkan ketelambatan pada jadwal pengerjaan yang sudah ditentukan. Kurangnya pengalaman dan keahlian personil kerja baik itu dalam perencanaan maupun pelaksanaan dapat menurunkan kualitas pekerjaan baik dari segi mutu, biaya dan waktu.

\section{KESIMPULAN DAN SARAN}

\section{Kesimpulan}

Berdasarkan hasil penelitian yang dilakukan, dapat disimpulkan beberapa hal sebagai berikut:

1. Metode identifikasi risiko yang paling banyak digunakan pada proyek infrastruktur adalah kuisioner.

2. Hampir semua (10 dari 13) jurnal yang diteliti menggunakan lebih dari 1 metode identifikasi risiko.

3. Kategori risiko yang paling banyak dibahas pada proyek infrastruktur adalah;

a) material dan peralatan 
b) manusia

4. Risiko yang paling banyak dibahas pada proyek bangunan gedung adalah:

a) Kategori risiko material dan peralatan: kenaikan harga material.

b) Kategori risiko manusia: kecelakaan tenaga kerja.

5. Risiko yang paling banyak dibahas pada proyek prasarana transportasi adalah:

a) Kategori risiko material dan peralatan: tidak tersedianya atau kekurangan material.

b) Kategori risiko manusia: rendahnya kualitas tenaga kerja.

\section{Saran}

Berdasarkan analisis dan pembahasan yang telah dilakukan pada penelitian ini, beberapa hal yang dapat disarankan untuk penelitian selanjutnya antara lain:

1. Pada penelitian selanjutnya dapat dilakukan pada jenis proyek infrastruktur yang berbeda sebagai contoh: proyek infrastruktur kerairan (drainase dan irigasi).

2. Pada penelitian ini kategori risiko proyek infrastruktur yang diteliti berjumlah 2 jenis yaitu: material dan peralatan, dan manusia. Pada penelitian selanjutnya dapat dilakukan pada jenis kategori risiko proyek infrastruktur yang berbeda.

\section{DAFTAR PUSTAKA}

Al-Bahar, J.F. and K.C. Crandall. "Systematic Risk Management Approach for Construction Projects." Journal of Construction Engineering and Management (1990).

Darmawi, Herman. Manajemen Risiko. Jakarta: Bumi Aksara, 2008.

Duffield, C \& Trigunarsyah, B. Project Management Conception to Completion. Australia: Engineering Education Australia , 1999.

Fahmi Wati Iribaram, Miftahul Huda. "Analisa Resiko Biaya Dan Waktu Konstruksi Pada Proyek Pembangunan Apartemen Biz Square Rungkut Surabaya." Jurnal Rekayasa dan Manajemen Konstruksi (2018): 141-154.

Fisk, E.R. Construction Project Administration Fifth Edition. New Jersey: Prentice Hall, 1997.

Hanafi, M. Manajemen Risiko. Yogyakarta: Yogyakarta: Unit Penerbit Dan Percetakan Sekolah Tinggi Manajemen YKPN, 2006.

Iwan M. Ramdan, Hanna Novita Handoko. "Kecelakaan Kerja Pada Pekerja Konstruksi Informal Di Keluarahan "X" Kota Samarinda." JURNAL MKMI (2016): 12.

Kangari, R. "Risk Management Perceptions and Trends of U.S. Construction." Journal of Construction Engineering and Management (1995).

Kerzner, Harold. "Project Manajement, a System Approach to Planning, Scheduling and Controlling." 1995.

Loosemore, et al. "Risk Management in Projects." (2006).

Mustami, Adinda Ade. Harga bahan bangunan naik 0,28\% setiap bulan. Oktober 2017. $<$ https://nasional.kontan.co.id/news/harga-bahan-bangunan-naik-028-setiap-bulan>.

Nasir B. Siraj and Aminah Robinson Fayek. "Risk Identification and Common Risks in Construction: Literature Review and Content Analysis." 2019.

Novita Sari, Endang Mulyani, Safarudin M.Nuh. "Manajemen Risiko Keselamatan Dan Kesehatan Kerja Pada Pekerjaan Konstruksi." 2013.

PMBOK. A GUIDE TO THE PROJECT MANAGEMENT BODY OF KNOWLEDGE. Pennsylvania: Project Management Institute, Inc., 2008.

Prasetyo, Indra Pandu. Analisis Keterlambatan Dan Kualitas Hasil Pekerjaan Pada Proyek Konstruksi. Depok: Universitas Indonesia, 2012.

Shen, George Wu and Catherine S. K. Ng. "Risk Assessment for Construction Joint Ventura in China." Journal of Construction Engineering and Management-ASCE (2001).

Siahaan, Fanny. "Tinjauan Tentang Pekerjaan Arsitektur Dalam Proyek Konstruksi Dengan Pendekatan Pada Bangunan Gedung Bertingkat." SCALE (2015).

Soeharto, I. Manajemen Proyek (Dari Konseptual Sampai Operasional). Jakarta: Erlangga, 1999.

—. Manajemen Proyek dari konseptual sampai operasional. Jakarta: Erlangga, 1995.

Soemarno, M.S. Risiko Penggunaan Lahan dan Analisisnya Laboratorium PPJP Jurusan Tanah. Malang: FPUB, 2007. 